\title{
MORPHOLOGICAL STUDIES ON THE FRESHWATER SNAIL CLEOPATRA BULIMOIDES (OLIVIER) (PROSOBRANCHIA - THIARIDAE ) 2- THE NERVOUS SYSTEM
}

\author{
Reda H. Aly \\ Department of Zoology, Faculty of Science, Ain Shams University
}

Key words: Cleopatra, Prosobranchia, anatomy, neurosecretion, nervous system.

\begin{abstract}
I nvestigations of the pattern of neurosecretion in the prosobranch snail cleopatra bulimoides were carried out. The nervous system consists of four paired and three unpaired ganglia. They are connected to each other by commissures and connectives. Although neurosecretory cells are present in all the ganglia examined, they are lacking in both connectives and commissures. The neurosecretory cells are classified into three types; two of them (A and B) are distributed all over the nervous system, while the third type $(C)$ is localized only within the cerebral ganglia. Cleopatra bulimoides acts as an intermediate host for the digenetic trematode Gastrodiscus aegypticus, a parasite of cattle.
\end{abstract}

\section{INTRODUCTION}

Several studies had been carried out on the macroscopic anatomy of many prosobranch snails such as Lanistes carinatus, Pomatiopsis lapidaria, Oncomelania hupensis, Pila globosa and Thias bufo (Demian, 1958; Davis, 1967; Narian and Singh, 1982; Rajalakshmi et al., 1983). The presence of neurosercretory cells within the nervous system of prosobranch snails were earlier investigated by Scharrer (1935) and Gape (1953). The latter stated that neurosecretory cells in Monotocardia are found in various ganglia, espacially the pleural and supraintestinal while they are absent from the buccal and pedal ganglia in all genera studied. In contrast to other gastropods, relatively little attention has been focused on aspects of neurosecretion in prosobranch snails (Simpson et al., 1964; Rajalakshmi Bhanu, ef al.. 1983: Francesco, 1989; Ibrahim et at., 1393: $1 \mathrm{~cm}$ and Aly, 1097). The control and regulation of bodily 
functions by neursecretory mechanism in mollusc snails were investigated by Martoja (1972) and Joosse (1988).

Presence of two types of neurosecretory cells in the nervous system of Melaria scabra, Bellamya unicolor and Lanistes carinatus were described by Nagabushanam and Muely (1974), Ibrahim et al. (1993) and Sleem and Aly (1997) respectively.

The main objective of the present work is to investigate the neurosecretory cell types of the ganglia of the prosobranch snail Cleopatra bulimoides.

\section{MATERIAL AND METHODS}

Adult snails were collected from irrigation canal in Giza Governorate. The specimens were kept in the laboratory, in glass aquaria with dechlorinated tap water. They were fed on fresh lettuce leaves. The macroscopic anatomy of the nervous system was investigated in narcotized snails. Gross dissection was done under a dissecting microscope in washed dishes. The nervous system was immersed in a diluted solution of methylene blue. The nervous system was drawn under binocular dissecting microscope using camera lucida. For histological studies, the nervous system was fixed either in Bouin or Zenker formol immediately. The fixed tissues were dehydrated, cleared, mounted, sectioned $(6 \mu \mathrm{m})$ and stained with haematoxylineosin, paraldehyde fuchsin and chrome hematoxyline phloxin (HE, PF and CHP).

\section{RESULTS}

\section{Anatomy:}

The nervous system of Cleopatra bulimoides is hereby described as far it is known, for the first time. The nervous system is composed of eleven ganglia, four paired and three unpaired ones. They are attached to each other by commissures and connectives. The central nervous system of $C$. bulimoides forms a compact circumoesophageal ring. This ring is composed of four paired ganglia; buccal, cerebral, pleural and pedal which are closely attached to each other. Three unpaired ones are supraoesophageal, suboesophageal and visceral (Figs. 1a, b, 2\&3). 
Morphological studies on the freshwater snail Cleopatra 215 bulimoides (Olivier) (Prosobranchia - Thiaridae). 2- The nervous system

A pair of buccal ganglia are attached to each other by a long commissure (Fig.2). These ganglia are connected to cerebral ganglia by long cerebrobuccal connectives. Three nerves arise from each ganglion to supply the oesophagus by oesophageal nerve, the salivary gland by salivary gland nerve and the radular sheath, the odontophoral cartilage and the muscles by ventral buccal nerve (Fig.2).

The cerebral ganglia are located at the dorsolateral sides of the buccal mass. They are connected to each other by a short commissure. From each of cerebral ganglion arise three connectives to the buccal, pleural and pedal ganglia respectively forming the cerebrobuccal, cerebropleural and cerebropedal connectives (Fig. 1a,b). Five paired nerves arise from these ganglia namely: optic, tentacular, superior labial and median lip nerves 1 and 2 .

The pleural ganglia are small and lie ventral to the cerebral ones. They are connected with three ganglia: cerebral ganglia (by the cerebropleural); pedal ganglia (by the pleuropedal) and oesophageal ganglia (by short left pleuroeosophageal connective with the suboesophageal ganglion and long right pleuroesophageal connective with the supraoesophageal ganglion) (Fig. 1 a,b). No detectable nerves arise from the pleural ganglia.

Meanwhile, the oesophageal ganglia are localized above and below the left cerebral ganglion (Fig.1a). The supraoesophageal ganglion gives off one nerve; the osphradial nerve (Fig. 1a). However, the suboesophageal ganglion lies just beneath the left cerebral ganglion and gives off the mantle and mid columellar nerves (Fig. 1a).

The pedal ganglia are large and located on the floor of the head region. These ganglia are attached to each other by pedal commissure. The previous ganglia are connected with cerebral and pleural ganglia. Five nerves arise from each ganglion to innervate the foot. Two of them are thick; anterior and posterior pedal nerves and the rest are thin and small (Fig. 1b).

The visceral ganglion is small, oval and localized at the base of the visceral mass. This ganglion is connected to the oesophageal ganglia through subvisceral and supravisceral connectives. The latter connective gives off one nerve to supply the heart, while the former ganglion gives off two branches to the gonad and ureter (Fig.3). 


\section{Histology:}

The nervous system of Cleopatra bulimoides is ensheathed with a perineurium which is provided with blood vessels (Figs. 4\& 6). The neurosecretory cells (NSCs) are mostly located at the peripheral portion of all ganglia examined and arrange in radiating groups (Figs. 4, 6, 8, 9 \& 10). Almost all the NSCs seem to be of unipolar type, sending their axons into the neuropile of the ganglia. No NSCs were seen in the connectives and commissures of the nervous system. There are three types of neurosecretory cells represented by large "A" cell $(5.6-8 \mu \mathrm{m})$, small "B" cell $(2.3-4.1 \mu \mathrm{m})$ and " $\mathrm{C}$ " cell $(1.7$ $2.3 \mu \mathrm{m})$.

In the buccal ganglia, the neurosecretory cells (NSCs) are differentiated into $\mathrm{A} \& \mathrm{~B}$ cell types and they appeared blue with haematoxylin eosin (Figs $4 \& 5$ ).

The cerebral ganglia are ensheathed by a thick perineurium (Fig.6). The NSCs in these ganglia are classified into A,B \& $\mathrm{C}$ types. The A cell is large pyriform and few in number, while B type is smaller oval and more dominant. Moreover, the two cell types have the same properties of staining reaction with (HE) and (CHP) (Figs. 6\&7). Presence of two dorsal organs correspond to juxtaganglionaire which included the $C$ cell type.

The NSCs in the pleural ganglia are scattered throughout the peripheral region. They could be divided into two cell types, which took blue colour wih HE (Figs.6 \&8).

The oesophageal (sub and supra) and visceral ganglia are characterized by the presence of a more dominating B cell type than A cell type. Their neurosecretory products exhibited a violet colour with (PF) (Fig. 9).

NSCs in the pedal ganglia are of A and B cell types and these ganglia are characterized by the presence of a statocyst which is provided by statoliths (Fig.10).

\section{DISCUSSION}

Variable numbers of ganglia and nerves supplying different organs were described in other prosobranchs by many authors (Demian, 1958; Rajalakshmi Bhanu,1983). They demonstrated eight ganglia in Lanistes carinatus and Thias bufo. However, Pila globosa constitutes three pairs of ganglia (Narian and Singh. 1982). Moreover, Bellamya unicolor and Melania scabra are provides with nine and 
Morphological studies on the freshwater snail Cleopatra 217

bulimoides (Olivier) (Prosobranchia - Thiaridae). 2- The nervous system

eleven ganglia respectively ( Nagabushanam and Mueleylbrahim et al., 1993)

The NSCs are concentrated at the peripheral regions of the ganglia and completely absent in the connectives and commissures. These observations were in accordance with the investigations of Nagabushanam and Muley, (1974), Narian and Singh (1983), Ibrahim et al. (1993) and Sleem and Aly (1997) on Melania scabra, Pila globose, Bellamya unicolor and Lanistes carinatus respectively. About twenty-five Monotocardia prosobranch snails were examined by Gape (1953). He found that the NSCs are absent from buccal and pedal ganglia in all genera studied.

By using different neurosecretory stains, the NSCs in the nervous system of $C$. bulimoides can be differentiated into three cell types, $A, B$ and $C$. The A cell type is large pyriform and few in almost all ganglia. B cell type is small, oval and formed the majority of the NSCs in all examined ganglia. On the other hand, the C type was only represented in the juxtaganglionarie attached to the cerebral ganglia. Variable numbers of NSCs were described in all the ganglia of the nervous system of some prosobranch snails. One cell type in Pila virens (Shylajan \& Alexander, 1977), two cell types in Bellamya unicolor and Lanistes carinatus (Ibrahim et al., 1993; Sleem \& Aly, 1997), three cell types in Amyclina corrnicium and Cyclope neritea (Francesco, 1989) and four in Pila globosa (Narian \& Singh, 1982).

The secretory products appear as fine granules, giving a homogeneous appearance to the cells. These neurosecretory cells took similar staining properties by the routine neurosecretory stains. Comparable results discussed the types of NSCs in different snails by Nagabushanam and Muley (1974), Shylajan and Alexander (1977), Rajalakshmi . Bhanu et al. (1983), Ibrahim et al. (1993) Sleem and Aly (1997).

The issue of neurohaemal areas in gastropods appears rather obscure, and particularly little seems to be known about these areas in prosobranchs (Narian \& Singh, 1982). However, a definite neurohaemal organ juxtaganglionarie can be found in prosobranchs and opisthobranchs attached to the cerebral ganglia (Martoja, 1965; Tombes, 1970). However, pulmonate snails have dorsal bodies localized at the dorsal sides of the cerebral ganglia. These bodies have the ability to stimulate oocytes growth and development and synthetic activity of the female accessory sex glands (Geraerts \& Jonsse. 1975 Wijdones et al. 1983; Brink, 1990). 


\section{REFERENCES}

Brink, M. (1990). How trematode parasites interfere with repoduction of their intermediate hosts, freshwater snails, J. Med. \& Appl. Malacol., 2 : $101-133$.

Davis, G.M. (1967). The systematic relationship of Pomatiosis lapidaria and Oncomelania hupensis formosana (Prosobranchia : Hydrobiidae). Malacol., 6 (1-2): 1-143.

Demian, E. S. (1954). The macroscopic anatomy of Lanistes carinatus Olivier. M.Sc. Thesis, Ain Shams Univ., Cairo.

Francesco, M. (1989). A comparative study of the neurosecretory system in two gastropod Mollusca, Amyclina cornicium Olivier and Cyclope neritea L. Nassariidae, Prosobranchia stenoglossa). Zool. Anz., 223(5-6): 341350.

Geraerts, W.P.M. and Joosse, J. (1975). The control of vitellogenesis and growth of female accessery sex organs by the dorsal body hormone (DBH) in the hermaphrodite freshwater snail Lymnaea. General and comparative Endocrinol., $27: 450-467$.

Ibrahim, A. M.; Saad, A. A. and Sleem, S. H. (1993). The neurosecretory system in the freshwater prosobranch, Bellamya unicolor. J. Facul. Educ., 18: 315-337.

Joosse, J. (1988). The hormones of molluscs. In Laufer, H.; Downer, G.H., eds." Endocrinology of Selected Invertebrate types" Vol II. New York: Alan R. Liss, 89-140.

Martoja, M. (1965): Existance d un organe juxtaganglionarie chez Aplysia punctata Cuv. (Gastrpode Opisthobranche). C.R. Acad. Sci. Paris, 260: 4615-4617.

Martoja, R. (1972). Endocrinology of mollusca; in" Chemical Zoology", M Florkin and Tscherrer eds (London: Academic Press), Vol. 7, 349 - 392. 
Morphological studies on the freshwater snail Cleopatra 219 bulimoides (Olivier) (Prosobranchia - Thiaridae). 2- The nervous system

Nagabushanam, R. and Muley, E. V. (1974). Studies on the neurosecretory system of a prosobranch, Melania scabra. Marthwada Univ. J. Sci., 13(6): 147-152.

Narian, A. S. and Singh, B. B. (1982). Neurosecretory cells in some principal ganglia of the common Indian apple-snail, Pila globosa. Arch. Biol. (Bruxelles), 93: 353-361.

Rajalakshmi Bhanu, R. C.; Shyamasundai, K. and Hanunantha Rao, K. (1983). The structure and cytochemistry of the neurosecretory cells in the intertidal gastropod Thais bufo (Lamarch) Z. Mikrosk. Anat. Forsh. Leipzig. 973 : 535-546.

Scharrer, B. (1935).Uber des hanstrom sche organ X bei Opisthobranchierm. Pubb. 1.Staz. Zool. Napoli,15: 132142.

Shylajan, R. and Alexander, K, M. (1977). Neurosecretion in the freshwater prosobranch, pila virens L. Neurosecretion in the normal and aestiveting snails. Proc. Indian Acad. Sci., 86(B): 323-327.

Sleem, S. H. and Aly, R. H. (1997). Neurosecretory cells in some principal ganglia of the prosobranch snail Lanistes carinatus Olivier. Egypt. J. Histol., 20(1): 47-56.

Tombs, A.S., (1970)."An introduction to Invertebrate Endocrinology". Academic press, New York $\backslash$ London.

Wijdenes, J.; Elk, R. van and Joosse, J. (1983) . Effects of two gonadotropic hormones on polysaccharide synthesis in the albumen gland of Lymnaea stagnalis, studied with the organ culture technique. General and Comparative Endocrinol., $51: 263-271$. 


\section{LEGENDS OF FIGURES:}

Fig. 1-a: Drawing of the nervous system of Cleopatra bulimoides from the dorsal view without buccal ganglia. $X 400$

Fig.1b: Drawing of the nervous system, where the cerebral commissure is cut and the two cerebral ganglia are reflected to the sides to clear the connectives, the pedal ganglia and their principal nerves arising from them $\mathrm{X} 400$.

Fig. 2: Drawing of the buccal ganglia and the main nerves.

Fig.3: Drawing of the nerves and connectives of the visceral ganglion. X400

Figs. 4-10: Photomicrographs of different ganglia to show

Fig. 4: the two buccal ganglia, buccal commissure and oesophagus. The ganglia are covered by perineurium, HE. X160

Fig. 5: the $\mathrm{A}$ and $\mathrm{B}$ neurosecretory cells in the buccal ganglia, $\mathrm{HE}$. X 1000

Fig. 6: the right cerebral and pleural ganglia, perineurium, neurosecretory cells, blood vessels (arrows) and oesophagus, HE. X 160

Fig. 7: the $\mathrm{A}$ and $\mathrm{B}$ neurosecretory cells in the cerebral ganglia, Chrome haematoxylin phloxin. X800

Fig. 8: the neuropile, the A and B neurosecretory cells in the pleural ganglion, H E. X1000

Fig. 9: the A and B cells in the suboesophageal ganglion, Paradehyde fuchsin. X1000

Fig. 10: the pedal ganglia and statocyst with lumen provided by statoliths. X160 


\section{LIST OF ABBREVIATIONS}

\begin{tabular}{|c|c|}
\hline$A$ & A cell \\
\hline Apn & anterior pedal nerve \\
\hline $\mathrm{B}$ & B cell \\
\hline $\mathrm{Bcm}$ & buccal commissure \\
\hline $\mathrm{Bg}$ & buccal ganglia \\
\hline Cbcn & cerebrobuccal connective \\
\hline $\mathrm{Ccm}$ & cerebral commissure \\
\hline $\mathrm{Cg}$ & cerebral ganglia \\
\hline Cpcn & cerebropedal connective \\
\hline Cplen & cerebropleurel connective \\
\hline $\mathrm{Gn}$ & gonadal nerve \\
\hline $1 \mathrm{plg}$ & left pleural ganglion \\
\hline$M_{1}$ & median labial nerve 1 \\
\hline $\mathrm{M}_{2}$ & median labial nerve 2 \\
\hline $\operatorname{mln}$ & midcolumellar nerve \\
\hline $\mathrm{mn}$ & mantle nerve \\
\hline np & neuropite \\
\hline o & oesophagus \\
\hline on & oesophageal nerve \\
\hline osn & osphradial nerve \\
\hline otn & optic nerve \\
\hline pcm & pedal commissure \\
\hline $\mathrm{Pe}$ & perineurium \\
\hline pg & pedal ganglia \\
\hline plocn & pleuroesophageal connective \\
\hline plpon & pleuropedal connective \\
\hline
\end{tabular}


prn

pspn

"plg

nn

San

$\operatorname{sog}$

srlin

srog

srven

St

stl

sven

ln

von

$\mathrm{Vg}$ pericardial nerve posterior nerve

right pleural ganglion renal nerve

salivary gland nerve

suboesophageal ganglion

supralabial nerve

supraoesophageal ganglion

supravisceral connective

statocyst

statoliths

subvisceral connective

tentacular nerve

ventral buccal nerve

isceral ganglion 


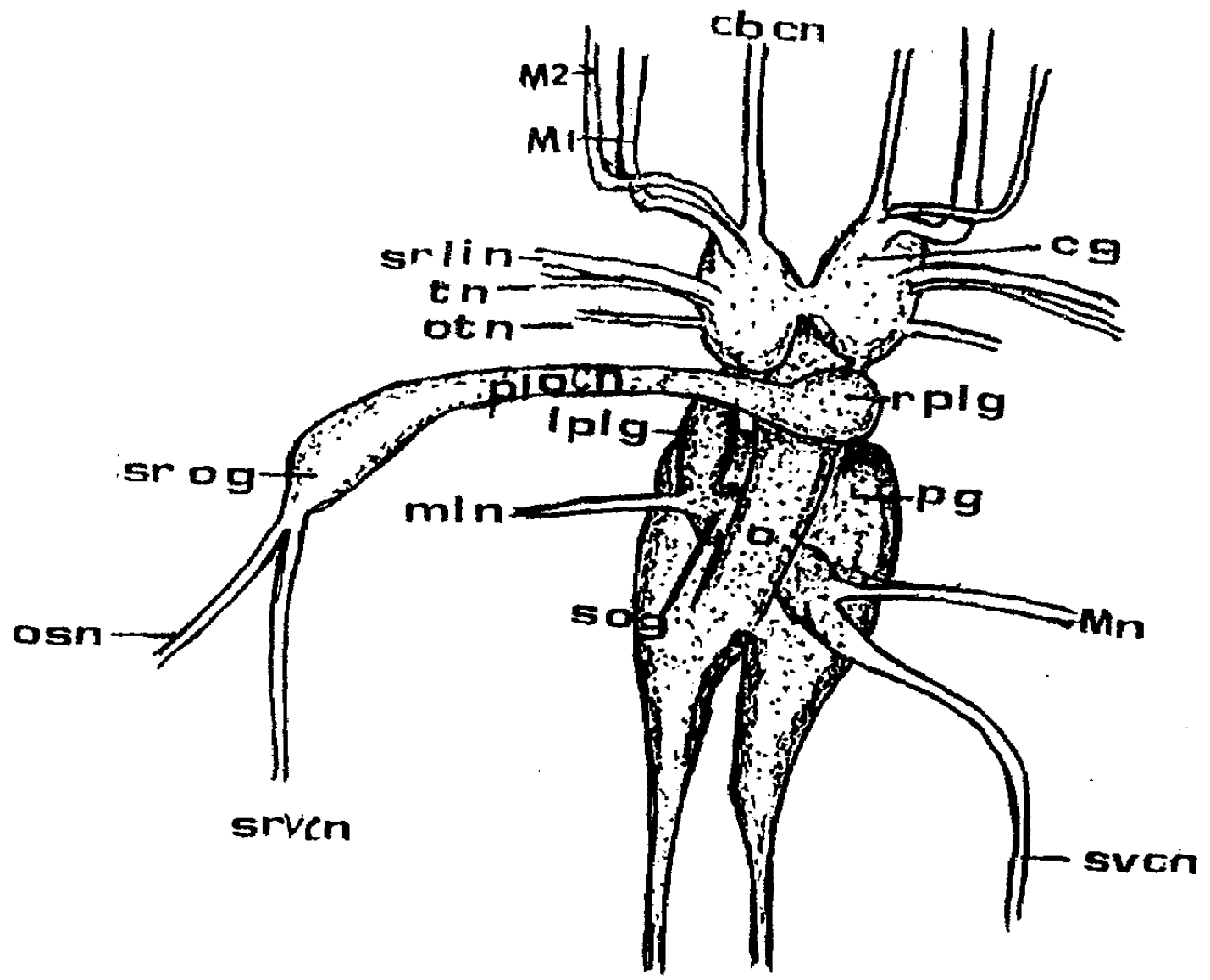

Fig la

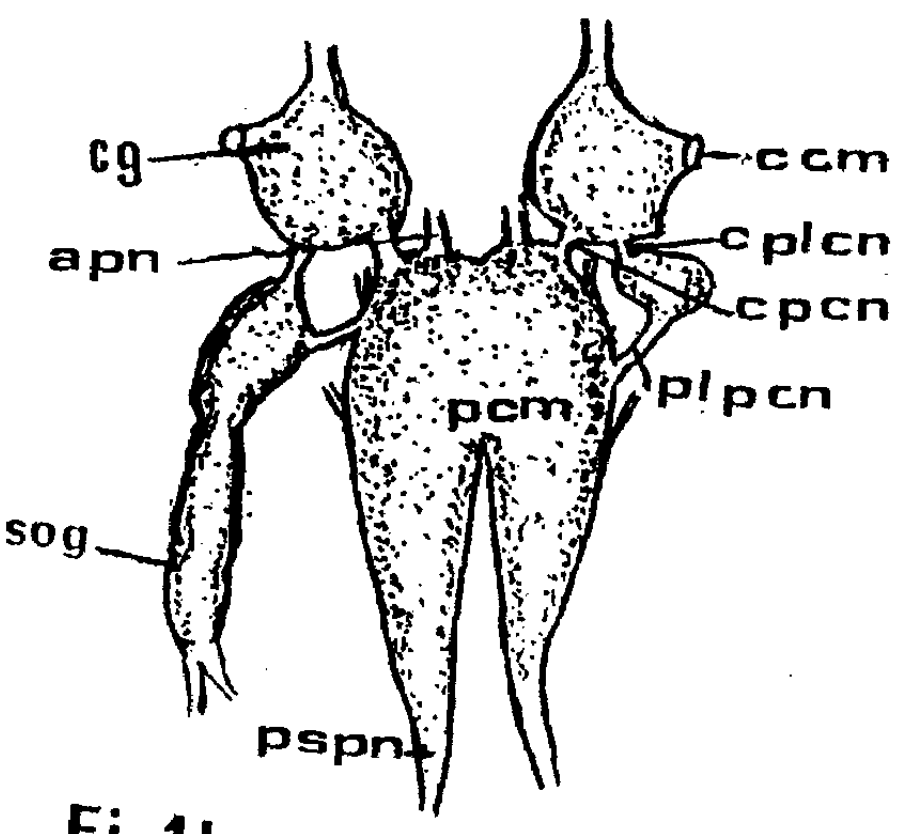

Fig1b

Fig 3

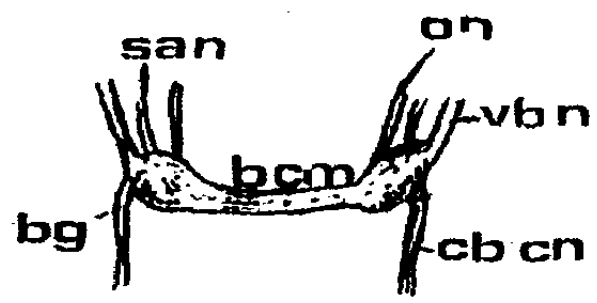

Fig 2

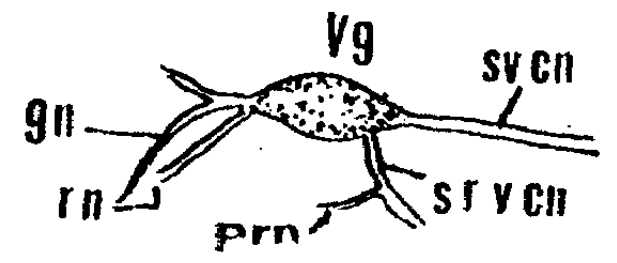




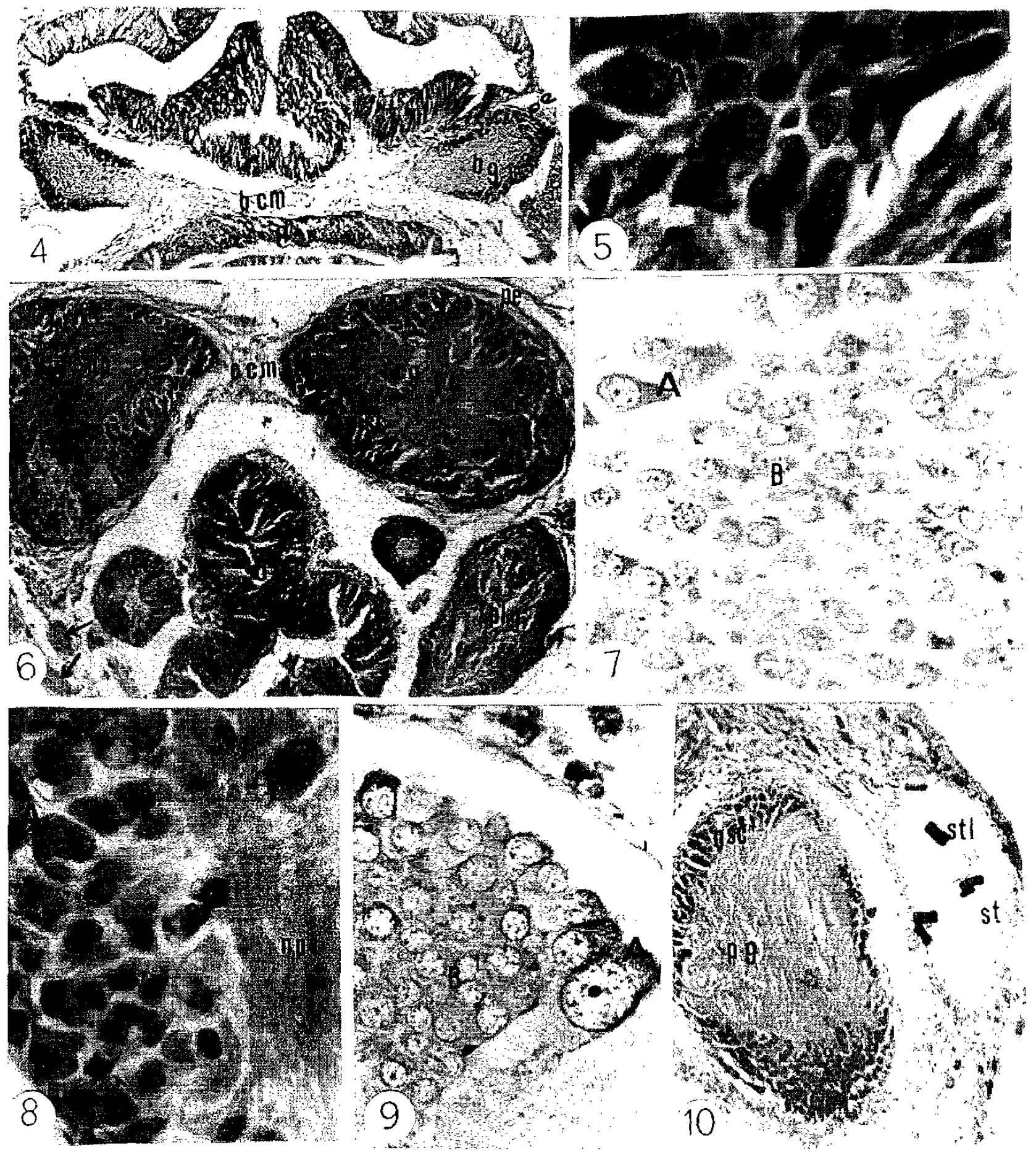

